\title{
SUGAR MOIETY HAS A DIRECT INFLUENCE ON THE SECONDARY STRUCTURE AND PROPERTIES OF STURGEON GONADOTROPIN
}

\author{
Henriks Zenkevičs*, Ilze Vosekalna**, and Vija Vose* \\ *Institute of Biology, University of Latvia, Miera iela 3, Salaspils, LV-2169, LATVIA \\ **Latvian Institute of Organic Synthesis, Aizkraukles iela 21, Rĩga, LV-1006, LATVIA
}

Contributed by Henriks Zenkevičs

\begin{abstract}
Sturgeon Acipenser güldenstädti Br. gonadotropic hormone (GTH) $\beta$-subunit ( $\beta$-GTH) was selectively chemically deglycosylated (dg) by anhydrous hydrogen fluoride and trifluoromethane

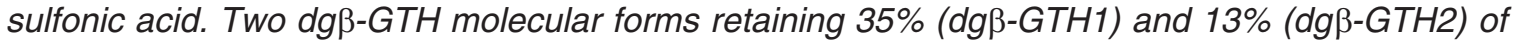
their initial carbohydrates were obtained. Investigation of the reassociated $\alpha-\beta$ hybrid dimers (recombinants) $\alpha-G T H+d g \beta-G T H 1$ and $\alpha-G T H+d g \beta-G T H 2$ showed that the immunoreactivity with antiserum raised against standard GTH dropped by $22.5 \%$. Hybrid dimers were recognised by the standard GTH antibodies, which indicated that the sugar moiety was not required for the counterpart subunit interaction. Hormonal activity of the $\alpha-G T H+d g \beta-G T H 1$ dropped twofold while the hybrid dimer $\alpha-G T H+d g \beta-G T H 2$ completely lost its activity in in vitro tests on the frog oocytes. $C D$-spectra indicated considerable changes in the secondary structure of the $\alpha-G T H+d g \beta-G T H 2$ : content of the $\beta$-structures decreased fourfold, but disordered structure content increased by $52 \%$ in comparison with that of the standard $\alpha-G T H+\beta-G T H$. However, the individual dg $\beta-G T H 1$ and dg $\beta$-GTH2 did not show any considerable differences in their secondary structure in comparison with that of the standard subunit $\beta-G T H$. It was evident that the slightly changed secondary structure of the dg $\beta-G T H 2$ as such might not be able to produce drastic distortions in the hybrid dimer structure. A conclusion is made that the carbohydrate moiety of the $\beta-G T H$ has a predominant role as a direct stabiliser of the functionally effective secondary structure of the whole sturgeon GTH heterodimeric $\alpha-\beta$ molecule.
\end{abstract}

Key words: sturgeon gonadotropic hormone, $\beta$-subunit, deglycosylation, secondary structure of the $\alpha-\beta$ dimer, biological function.

\section{INTRODUCTION}

Sturgeon pituitary gonadotropic hormone (GTH) is a typical member of the glycoproteine hormone family. It has been shown that its carbohydrate moiety comprised up to $30 \%$ of the molecular mass (26 kDa) (Зенкевич, 1992). The hormone contains three asparagine-linked oligomannosidic and hybrid carbohydrate chains, two in the $\alpha$-subunit ( $\alpha$-GTH) and one in the $\beta$-subunit ( $\beta$-GTH) (Зенкевич и др., 1992 ).

Rather intensive investigations of the biological role of carbohydrates in mammalian gonadotropins have been carried out about 20-30 years ago and the role of the carbohydrate moiety in the specific biological function of the mammalian GTH-s has been well recognised (Bahl et al., 1984). Similar data were obtained by us for sturgeon GTH showing that deterioration in the carbohydrate moiety influenced the molecular properties of the hormone and modified its biological function (Зенкевич, 1992; Zenkevičs, 1994; Zenkevičs et al., 2000). Our previous studies of the molecular proper- ties of sturgeon GTH and its separate subunits showed that $\beta-G T H$, due to its high conformational rigidity (six $\mathrm{S}-\mathrm{S}$-bonds), serves as a core of the hormone heterodimeric molecule and may impart receptor-specific three-dimensional structure not only to the $\alpha$-GTH (one S-S-bond) but also to the whole $\alpha-\beta$ structure (Зенкевич, 1992). However, the effect of the $\beta$-GTH oligosacharide moiety on this function is not quite clear so far.

The goal of this work was to use a two-level selective chemical deglycosylation ( $\mathrm{dg}$ ) of the $\beta$-GTH to evaluate the role of its carbohydrate chain in maintaining the functionally effective secondary structure and biological activity of the hormone dimeric molecule.

\section{MATERIALS AND METHODS}

A highly purified preparation of sturgeon GTH was isolated from acetone-dried pituitary glands of sturgeon using gel- 
filtration and ion-exchange chromatography on DEAE-cellulose columns, according to the standard procedure described earlier (Зенкевич, 1992).

Individual $\alpha$ and $\beta$ subunits of GTH were isolated by ion-exchange chromatography on SE-Sephadex C-25 in $0.025 \mathrm{M}$ acetate buffer at $\mathrm{pH} 4.9$, after GTH dissociation in $8 \mathrm{M}$ urea according to Hennen et al., 1971.

Self-reassociation of subunits was carried out in saline $(12 \mathrm{~h})$ at room temperature at a total protein concentration of about $0.2 \%$, using counterpart subunits at an equimolar ratio. The GTH preparation was reconstituted from the native $\alpha$ and $\beta$ subunits by means of reassociation and used throughout the study.

Double immunodiffusion tests in $1 \%$ agar gel (Bacto-agar Difco, U.S.A.) in veronal buffer (ionic strength $0.05, \mathrm{pH}$ 8.6) were performed by Ouchterlony's method (Ouchterlony, 1958) using polyclonal monovalent antiserum, raised in rabbits, against highly purified sturgeon GTH.

The grass frog Rana temporaria L. oocyte in vitro maturation test (Thornton, 1971) was used to assess the gonadotropic activity of the purified standard hormone and subunit recombinants produced by the re-association of the counterpart subunits. The gonadotropic activity was expressed as the minimal dose of the hormone preparation that produced $50 \%$ oocyte maturation $\left(\mathrm{D}_{50}\right)$ (Zenkevics et al., 2005).

The deglycosylation of the $\beta$-GTH (10 mg, dried under vacuum) was carried out by anhydrous hydrogen fluoride (HF) (Fluka) (Manjunath and Sairam, 1982). The reaction was performed at $0{ }^{\circ} \mathrm{C}$ for $1.5 \mathrm{~h}$ in a stoppered teflon vial $(5 \mathrm{ml})$ in $2 \mathrm{ml}$ of $\mathrm{HF}$ condensed at $70{ }^{\circ} \mathrm{C}$ (dry ice and acetone). When the reaction ended HF was removed by a vacuumpump, dg $\beta$-GTH was applied to a Sephadex G-25 column $(1.2 \times 18 \mathrm{~cm})$ in $0.02 \mathrm{M} \mathrm{NH}_{4} \mathrm{HCO}_{3}, \mathrm{pH} 7.5$ and lyophilised.

Another portion of the $\beta-\mathrm{GTH}$ has been treated with trifluoromethane sulfonic acid (TFMS, Aldrich) to achieve deeper deglycosylation (Kalyan and Bahl, 1981). $10 \mathrm{mg}$ of the $\beta$-GTH was treated with $1.5 \mathrm{ml}$ of TFMS and $1.0 \mathrm{ml}$ moisture free anisole as a scavenger. The reaction mixture was incubated at $0{ }^{\circ} \mathrm{C}$ for $5 \mathrm{~h}$ under nitrogen in a screw cap vial with occasional shaking. The reaction was terminated by addition of $1.5 \mathrm{ml}$ of pyridine in $2 \mathrm{ml}$ water at $0{ }^{\circ} \mathrm{C}$ with shaking. After dialysis against water $\operatorname{dg} \beta-\mathrm{GTH}$ was desalted on Sephadex G-25 and lyophilised. It has been shown for gonadotropins that chemical deglycosylation does not affect the polypeptide moiety (Manjunath and Sairam, 1982).

Carbohydrate content in the $\beta$-GTH was assayed quantitatively by standard colorimetric methods of carbohydrate analysis using phenol- $\mathrm{H}_{2} \mathrm{SO}_{4}$ and Ehrlich's reagent (Zenkevičs, 1992).

Circular dichroism (CD) spectra were recorded using a Jasco J-710 spectropolarimeter over the wavelength range from 180 to $250 \mathrm{~nm}$ at $22-25^{\circ} \mathrm{C}$, in phosphate buffer, $\mathrm{pH}$
7.0. The spectropolarimeter was calibrated by epiandrosterone and 10-camphorsulphonic acid standards. For recording of spectra, $0.1-0.01 \mathrm{~cm}$ Helma quartz cells were used. The concentration of proteins in the solution was $10^{-3}-10^{-4} \mathrm{M}$. $\mathrm{CD}$ data are given in units of molar ellipticity per amino acid residue of an average relative molecular mass 108 . The content of various secondary structures in the preparations was calculated using the CDPro-CONTILL programme (Sreerama et al., 1999; Whitmore and Wallace, 2004; Lees et al., 2006). In our case CD spectra of 29-48 proteins were used for calculation of the secondary structure elements.

\section{RESULTS}

Treatment with anhydrous liquid HF removed $65 \%$ of the sugar moiety of $\beta-\mathrm{GTH}$, while application of TFMS removed up to $87 \%$ of the sugars. Thus, two deglycosylated $\beta-$ GTH molecular forms $\mathrm{dg} \beta-\mathrm{GTH} 1$ and $\mathrm{dg} \beta-\mathrm{GTH} 2$ containing 35 and $13 \%$ of their initial amount of carbohydrate units were obtained.

Using recombination or self-re-association of the standard $\alpha-\mathrm{GTH}$ with the deglycosylated $\beta-\mathrm{GTH}$, two types of the mixed $\alpha-\beta$ hybrid GTH dimer structures $\alpha-\mathrm{GTH}+$ $\operatorname{dg} \beta-$ GTH 1 and $\alpha-G T H+\operatorname{dg} \beta-G T H 2$ were reconstituted. The mixed hybrids were prepared to evaluate the structural - functional importance of the carbohydrate moiety of the $\beta$-GTH in sturgeon GTH $\alpha-\beta$ dimer structure, since the native hormone molecule is built of two non-covalently complementary bonded counterpart subunits.

Comparative assessment of the immunoreactivity and the specific gonadotropic activity of the hybrid recombinants and the native $\alpha$ - and $\beta$-GTH recombinant as a standard revealed (Table 1) that removal of a relatively large part of the carbohydrate moiety of the core $\beta$-GTH did not cause any substantial loss of the ability of the hybrid dimers to interact with the antibodies raised against standard GTH. As evident from Table 1, immunoreactivity of both modified dimers decreased on average only by $22.5 \%$ in comparison with that of the standard. The in vitro gonadotropic activity of $\alpha-\mathrm{GTH}+\operatorname{dg} \beta-\mathrm{GTH} 1$ was lower by $50 \%$ while $\alpha-\mathrm{GTH}+$ $\mathrm{dg} \beta-\mathrm{GTH} 2$ was completely inactive.

As is seen from the CD spectra (Fig. 1), a negative band around wave length 193-197 $\mathrm{nm}$ and shoulder at 205 and $215 \mathrm{~nm}$ are well expressed for the standard dimer and for the hybrid dimer $\alpha-G T H+\operatorname{dg} \beta-G T N 1$. The shoulder (or two

Table 1

BIOLOGICAL PROPERTIES OF STANDARD AND HYBRID DIMERS COMPRISING dg $\beta$-GTH

\begin{tabular}{l|c|c|c}
\hline \multicolumn{1}{c|}{ Preparation } & Serum & $\begin{array}{c}\text { Hormon activity, } \\
\%\end{array}$ & $\begin{array}{c}\text { Immuno activity, } \\
\%\end{array}$ \\
\hline$\alpha-\mathrm{GTH}+\beta-\mathrm{GTH}$ & GTH & 100 & 100 \\
$\alpha-\mathrm{GTH}+\mathrm{dg} \beta-\mathrm{GTH} 1$ & GTH & 50 & 80 \\
$\alpha-\mathrm{GTH}+\mathrm{dg} \beta-\mathrm{GTH} 2$ & GTH & 0 & 75
\end{tabular}

$\overline{\mathrm{dg} \text {, deglycosylated. }}$. 


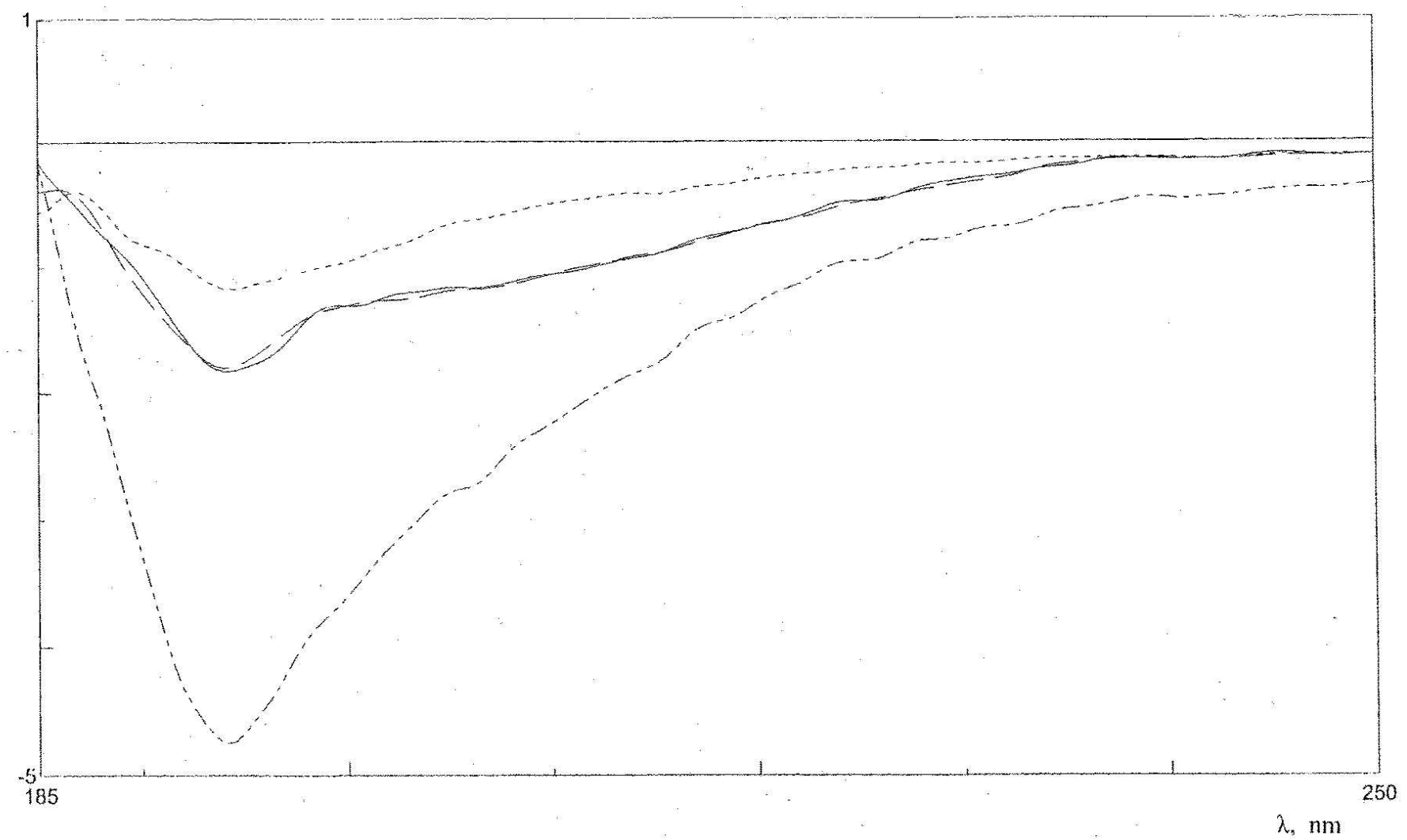

Fig. 1. CD spectra of standard $\alpha-G T H+\beta-G T H$, repeated twice $(=-\ldots)$ and hybrid combinants $\alpha-G T H+\operatorname{dg} \beta-G T H 1(--$ ) and $\alpha-G T H+$ $\operatorname{dg} \beta$-GTH2 (-........-).

weak negative bands) was not detected for $\alpha-\mathrm{GTH}+$ $\mathrm{dg} \beta-\mathrm{GTH} 2$. The negative Cotton effect around $195 \mathrm{~nm}$ is close to the well known negative band of the random coil at $198 \mathrm{~nm}$, while the shoulder and the negative band (around 205 and $215 \mathrm{~nm}$ ) could arise from the significant contribution of the $\beta$-structures, influenced by a minor amount of $\alpha$-helix (Lees et al., 2006).

The results of the calculations of the content of various secondary structures, shown in Table 2, allowed to conclude that the spatial structure of the standard dimer and $\alpha-\mathrm{GTH}+$ dg $\beta$-GTH1 are quite similar, while that of $\alpha-\mathrm{GTH}+$ $\operatorname{dg} \beta-G T H 2$ is considerably altered-content of the $\beta$-type structures drastically decreased (fourfold), and random coil

Table 2

TYPES OF THE SECONDARY STRUCTURE (\%) OF STANDARD AND HYBRID DIMERS COMPRISING dgB-GTH AND OF INDIVIDUAL STANDARD $\beta$-GTH AND dg $\beta$-GTH2

\begin{tabular}{l|c|c|c|c}
\hline \multicolumn{1}{c|}{ Preparation } & $\alpha$ & $\beta$ & $\beta_{\mathrm{t}}$ & $\mathrm{R}$ \\
\hline$\alpha$-GTH $+\beta$-GTH & 2.6 & 30.1 & 17.8 & 49.6 \\
$\alpha$-GTH $+\operatorname{dg} \beta$-GTH1 & 2.6 & 34.4 & 17.0 & 45.9 \\
$\alpha$-GTH+ dg $\beta$-GTH2 & 2.6 & 8,5 & 13.4 & 75.4 \\
$\beta-$ GTH & 7.0 & 44.0 & 12.0 & 37.0 \\
$\operatorname{dg} \beta-$ GTH2 & 6.0 & 38.0 & 15.0 & 37.0
\end{tabular}

$\alpha, \alpha$-helix; $\beta$, parallel and antiparallel $\beta$-strand; $\beta$ t $\beta$-turn; $R$, random coil; $\mathrm{dg}$, deglycosylated. or disordered structure content increased by $52 \%$ in comparison with that of the standard.

\section{DISCUSSION}

The comparative investigation of the hormonal activity and immunologic function indicated quite clearly that the removal of a considerable part of the $\beta$-GTH carbohydrate moiety (dg $\beta$-GTH1and dg $\beta$-GTH2) produced only a slight decrease in the immunoreactivity of both hybrid dimers in comparison with that of the standard (Table 1). Also, both hybrid dimers revealed immunologic identity with the standard dimer and native GTH in double diffusion tests with the antiserum raised in rabbits against standard GTH. This clearly demonstrates that the carbohydrates of the $\beta$-subunit are not involved in the association of the counterpart subunits, and also confirms that the antigenic binding sites (determinants) are not located in the carbohydrates.

Unlike immunological properties, hormonal activity of the dimers decreased drastically: $\alpha-\mathrm{GTH}+\mathrm{dg} \beta-\mathrm{GTH} 1$ lost half of its initial activity, while $\alpha-\mathrm{GTH}+\operatorname{dg} \beta-\mathrm{GTH} 2$ indicated no gonadotropic activity in the hormone-specific and sensitive tests on frog oocytes (Table 1). As evident from Table 2 , the three-dimensional spatial structure was highly disordered by the substitution of the native $\beta-\mathrm{GTH}$ in $\alpha-\beta$ dimer with its analogue $\operatorname{dg} \beta-\mathrm{GTH} 2$, in which carbohydrate content was reduced by $87 \%$. In this case the regularity of pro- 
tein structure of the dimer was drastically lowered - decreased content of the $\beta$-type structures and considerably increased content of the disordered structures which can be considered as random coil. Nevertheless, this did not prevent the formation of the dimer structure typical of the hormone and recognised by the standard GTH antibodies (Table 1). However, when $\operatorname{dg} \beta-\mathrm{GTH} 1$ was recombined with the standard counterpart $\alpha$-GTH, the secondary structure of the resulted hybrid dimer was quite similar to that of the standard dimer and showed $50 \%$ of the standard hormone response level in the specific bio-tests. Apparently the conformational features of the hybrid dimer required for receptor recognition and combining with the hormone specific antibodies are still present. This clearly indicated that full integrity of the carbohydrate moiety is not required for the subunit interaction, membrane receptor binding and the hormonal signal translocation into the cell. It is relevant to mention here that the same was earlier observed also for mammalian gonadotropic hormones (Manjunath and Sairam, 1982; Bahl et al., 1984).

The comparison of the secondary structure of the individual standard $\beta-G T H$ and dg $\beta-G T H 2$ (Zenkevich et al., 1999) did not reveal any considerable differences (Table 2). This indicated that even the stronger deglycosylation of the $\beta$-subunit did not cause any serious conformational transformations in its protein structure. Thus, the removal of the greater portion $(87 \%)$ of the carbohydrate moiety by the treatment with TFMS produced only slight conformational shifts in the protein structure of the $\mathrm{dg} \beta-\mathrm{GTH} 2$ (Table 2). It seems improbable that the $\mathrm{dg} \beta-\mathrm{GTH} 2$ with a slightly modified spatial structure of its protein part, being enclosed into the $\alpha-\beta$ structure by counterpart subunit recombination, might cause such a large conformational change in the protein moiety of the whole dimeric molecule, such as observed in the hybrid $\alpha-\mathrm{GTH}+\operatorname{dg} \beta-\mathrm{GTH} 2$.

It is evident that the slightly changed secondary structure of the $\operatorname{dg} \beta-\mathrm{GTH} 2$ as such may not be the decisive factor for producing drastic distortions in the re-associated hybrid dimer molecular structure. The massive carbohydrate chain of the $\beta-$ GTH may have a specific simultaneous interaction with both subunits, lending stability to the $\alpha-\beta$ dimer and maintaining the receptor-specific three-dimensional structure of the whole molecule. The treatment with TFMS led to almost entire removal of the sugar moiety of the $\beta-\mathrm{GTH}$ and to the total loss of sialic acids, eliminating the strong electronegative charge. This probably may interrupt specific stabilising interactions between the carbohydrate chain of the $\beta$-GTH and the protein moiety of the hormone, producing in such a way the strong conformational shifts in species-specific receptor-sensitive three-dimensional structure.

In conclusion, the above studies clearly show that the carbohydrate moiety of the $\beta-\mathrm{GTH}$ has a predominant role as a direct stabiliser of the functionally effective secondary structure of the whole sturgeon GTH heterodimeric $\alpha-\beta$ molecule.

\section{ACKNOWLEDGEMENTS}

This work was supported by the Latvian Council of Science, grants 05.1412 and 05.1791 .

\section{REFERENCES}

Bahl, O.P., Thotakura, N.R., Anumula, K.R. (1984). Biological role of carbohydrates in gonadotropin. In: Hormone Receptors in Growth and Reproduction. Sirano Symposium Publications. Vol. 9 (pp. 165-183). Raven Press, New York.

Hennen, G., Prusik, Z., Maghuin-Rogister, G. (1971). Porcine luteinizing hormone and its subunits. Eur. J. Biochem., 18, 376-383.

Kalyan, N.K., Bahl, O.P. (1981). Effect of deglycosylation on the subunit interactions and receptor binding activity of human chorionic gonadotropin. Biochem. Biophys. Res. Commun., 102(4), 1246-1253.

Lees, J.G., Miles, A.J., Wien, F., Wallace, B.A. (2006). A reference database for circular dichroism spectroscopy covering fold and secondary structure space. Bioinformatics, 22, No. 16, 1955-1962.

Manjunath, P., Sairam, M.R. (1982). Biochemical, biological, and immunological properties of chemically deglycosylated human choriogonadotropin. J. Biol. Chem., 257(12), 7109-7115.

Ouchterlony, O. (1958). Diffusion-in-gel methods for immunological analyses. Progr. Allergy, 5, 1-6.

Sreerama, N., Venyaminov, S.Y., Woody, R.W. (1999). Estimation of the number of alpha- helical and beta-strand segments in proteins using circular dichroism spectroscopy. Protein Sci., 8, 370-380.

Thornton, V.F. (1971). A bioassay for progesterone and gonadotropins based on meiotic division of Xenopus oocytes in vitro. Gen. Comp. Endocrionl., 16, 599-605.

Whitmore, L., Wallace, B.A. (2004), DICHROWEB, an online server of protein secondary structure analyses from circular dichroism spectroscopic data. Nucleic Acid Res., 32, W668-W673.

Zenkevičs, H. (1994). Fish gonadotropic hormone: Structural-functional investigations. Proc. Latvian Acad. Sci., Section B, No. 5/6, 82-88.

Zenkevics, H., Klavins, M., Vose, V., Bucena, A. (2005). Humic acid reduces gonadotropin activity and hormonal sensitivity of frog oocytes. Aquatic Toxicology, 75, 380-383

Zenkevičs, H., Vose, V., Vosekalna, I., Būcena, A. (2000). Partial deglycosylation of alpha subunit modifies sturgeon gonadotropin function. Acta Biochim. Pol., 47(3), 815-819.

Zenkevich H.A., Vose V.A., Vosekalna I.A., Butsena A.Ya. (1999) Functional role of the carbohydrate moiety of the sturgeon gonadotropin $\beta$-subunit. Doklady Biochemistry, 364, 24-27.

Зенкевич, Г.А. (1992). Гонадотропный гормон рыб: получение и свойства [Fish Gonadotropic Hormone: Isolation and Properties]. Рига, Зинатне, 224 с. (in Russian).

Зенкевич, Г.А., Арбатский, Н.П., Сланке, В.П., Желтова, А.О., Деревицкая, В.А. (1992). Структура углеводных цепей димерной молекулы и отдельных субъединиц гонадотропина русского осетра [Structure of the carbohydrate chains of the dimeric molecule and individual subunits of the Russian sturgeon gonadotropin]. Биоорганическая химия, 18, 226-234 (in Russian). 


\section{STORES GONADOTROPĪNA CUKURU DAL,AI IR TIEŠA IETEKME UZ HORMONA OTRĒJO STRUKTŪRU UN İPAŠĪBĀM}

Stores gonadotropā hormona (GTH) $\beta$-subvienība ( $\beta$-GTH) tika k̦īmiski deglikozilēta (dg) ar bezūdens fluorūdeņradi (HF) un trifluormetilsulfoskābi (TFMS). Rezultātā tika iegūtas divas dg $\beta$-GTH formas - dg $\beta$-GTH1 un $\operatorname{dg} \beta$-GTH2 ar samazinātu cukuru saturu attiecīgi līdz 35 un 13\% salīdzinājumā ar standartsubvienību. Reasociācijas ceḷā ar $\alpha$-GTH tika iegūti GTH hibrīddimēri $\alpha-G T H+d g \beta-G T H 1$ un $\alpha-G T H+d g \beta-G T H 2$. To imūnreaktivitāte ar GTH antiserumu samazinājās vidēji par $22.5 \%$ salīdzinājumā ar standartdimēru $\alpha-G T H+\beta-G T H$. Hibrīddimēra $\alpha-G T H+\operatorname{dg} \beta-G T H 1$ hormonālā aktivitāte samazinājās par $50 \%$, bet $\alpha-G T H+\operatorname{dg} \beta-G T H 2$ gadījumā - pilnībā izzuda. CD spektroskopijas dati parādīja, ka dziḷās dg gadījumā notiek krasas izmaiṇas $\alpha$ tipa struktūrās (samazinās četrkārt), vienlaicīgi par 25\% pieaugot struktūras neregularitātei. Otrajā hibrīddimērā struktūras izmaiņas nebija būtiskas. Arī $\alpha$-GTH un dg $\beta$-GTH2 neuzrādīja krasas otrējās struktūras atšķirības. Parādīts, ka, atdalot 87\% $\beta$-GTH cukuru, subvienība vēl spēj specifiski saistīties ar natīvo $\alpha-$ GTH un veidot $\alpha-\beta$ dimēru, kuru atpazīst GTH antivielas. Lai arī dg $\alpha-G T H 2$ telpiskā struktūra nav būtiski izmainījusies, tās komplementācijas ar $\alpha$-GTH rezultātā veidojas hormonāli neaktīvs $\alpha-\beta$ dimērs ar krasi izmainītu telpisko struktūru. Secināts, ka $\beta$-GTH cukuru daḷi ir stabilizējoša ietekme uz hormona dimērmolekulas otrējo struktūru. Mijiedarbībā ar hormona olbaltumdaḷu tā nodrošina GTH receptorspecifisko konformāciju un pilnvērtīgu hormonfunkciju. 